\title{
The Hellenistic Period and Hellenization in Phoenicia a
}

\author{
Corinne Bonnet
}

The Oxford Handbook of the Phoenician and Punic Mediterranean

Edited by Brian R. Doak and Carolina López-Ruiz

Print Publication Date: Oct 2019 Subject: Archaeology, Archaeology of Eurasia

Online Publication Date: Aug 2019 DOI: 10.1093/oxfordhb/9780190499341.013.8

\section{Abstract and Keywords}

After Alexander's conquest, Phoenicia was at the heart of a cultural process whose complexity has not been adequately explained by the concept of "Hellenization." This chapter offers a critical questioning of this concept and a more fine-grained analysis of the cultural dynamics that resulted from the long-term contact of Phoenician peoples with Greek paideia. It is important to note that this process was largely before Alexander's arrival, and it varied greatly depending on the perspectives of the sources, which are rather few in number. By examining institutions, cult mediations, and the role of elites, this chapter restores the fluidity and creativity that characterized strategies of integrating newness and claiming ancestrality that were at work in the Phoenician "middle ground" during the Hellenistic period.

\section{The Question of Hellenization}

SINCE THE NINETEENTH century, the transformations affecting the entire Near East after Alexander's conquest have been understood through the concepts of "Hellenism" (Hellenismus, according to J. G. Droysen; see Payen 2005) and "Hellenization," which emphasize the impact of Greek culture on local cultures (Grainger 1992). However, today many researchers are uncomfortable with or even disagree with the use of these concepts, as they are permeated with colonial thought and cultural hierarchy. These scholars insist on the unique aspects of the Phoenician case, involving early contacts with the Aegean world and the Western diaspora diaspora (Millar 1983; Sartre 2003; Bonnet 2014). To describe and analyze the ethnic, political, social, economic, cultural, and religious recompositions in Phoenicia after $332 \mathrm{BCE}$, scholars now have tools, including those from anthropology and sociology, that enable them to reconstruct more precisely the complexity and fluidity of the situations reflected in the sources. 


\section{The Hellenistic Period and Hellenization in Phoenicia}

From the outset, however, it is important to note the regrettable documentary imbalance that has helped amplify the alleged impact of Greek culture in Phoenicia. The loss of all forms of "Phoenician literature" (see chapter 18, this volume), whatever the genres that may fall under this label, is a serious handicap. When trying to understand the consequences of the conquest, we have no direct evidence from the Phoenicians themselves other than a small group of inscriptions that date from long after the conquest and reveal little about the processes of cultural mixing. The silence of (p.100) the conquered people -because, as we shall see, the conquest of Alexander did lead to Greek control over Phoenician territories-prevents us from reconstructing both sides of the events. The impact of the conquerors' voice is thus amplified, reinforcing the idea that Phoenicia was "Hellenized," or in other words, actively or passively acculturated to Greek lifestyles and thought.

Recent work on Hellenistic Phoenicia (Sartre 2003; Bonnet, 2014; see also Aliquot 2009 for the Roman period), however, shows that this process was neither unilateral, nor uniform, nor automatic. Field work by anthropologists from a postcolonial perspective has found that the reception and domestication of new cultural products does not necessarily distort indigenous cultures but can, instead, contribute to the preservation, even growth, of traditional social relations. Faced with new things, whether imposed or requested, individuals' cultural creativity enables unexpected compromises to emerge, although not without occasional conflict. Human agency seems to be seen more among certain categories of people, such as elites, people traveling, or smugglers. Even in a context of domination that limits autonomy, people find new ways to strike a balance, while the amount of each culture in the mix is unpredictable. To speak of "Hellenism" is certainly to suggest a transformation process, but it also means attributing the decisive initiative and influence to the Greeks. It makes Phoenicians disappear under a Hellenic veneer: as we read too often in books about Phoenicia, Phoenician history apparently ended in 332 BCE.

Moreover, the concept of "Hellenism" presupposes the existence of two distinct and bounded entities- "Greek culture" and "Phoenician culture" - whereas on both sides we find composites. Alexander himself was a Macedonian leading a diverse army. As the task of the historian is to reconstruct the past in all its complexity, it is clear that the term "Hellenism" does not do justice to the processes of métissage, especially since this process of cultural interactions began before Alexander. These processes were in fact unstable, unbalanced, and highly differentiated according to the area (urban/rural) and to social categories (elites/ordinary people, men/women, etc.), or depending on the type of activities considered (such as business, politics, or religion). We are therefore very far from Droysen's idea of "fusion" (Verschmelzung), as well as the binary, antagonist visions of the colonial and postcolonial periods. Many studies by scholars of antiquity have touched on issues of identity, belonging, affiliation, and ethnicity (Kuhrt and SherwinWhite 1987; Hall 1997, 2002; Gruen 2005; Versluys 2008; Whitmarsh 2010; Stavrianopoulou 2013; Ager and Faber 2013). They have identified selective or cumulative dynamics along varying scales, such as a Tyrian or a Sidonian from a good family who has a Greek name, speaks and makes a show of his or her use of the Greek language (for example, in acts of devotion), and practices Greek forms of sociability at banquets and gymna- 


\section{The Hellenistic Period and Hellenization in Phoenicia}

siums, while still being attached to the cult of his or her ancestral gods and cultivating a sense of belonging to an ancient Phoenician lineage descending from Kadmos or Agenor. The fabric of Hellenistic Phoenicia is, in many ways, paradoxical (Ma 2008).

Studies on the connectivity specific to the Mediterranean at various times (Malkin 2011) now encourage us to think more in terms of networks that foster cultural (p. 101) interweaving, both before and after military conquests. Today, scholars focus on interactions in cultural dynamics along many scales: local, regional, supra-regional, and global. However, from Isocrates at least, Greek culture (paideia) sought to play a universalizing role, without stifling local cultures but, instead, offering them a voice to disseminate their culture on a more global level. For this reason, the current challenge for historians of Hellenistic Phoenicia is to make sense of these multiple arrangements between past and present and between micro identities and broadly shared references. These arrangements involved pragmatic strategies, negotiations, and compromises. They affected the social imaginary, common understandings, cultural transfers, and ways of being, acting, and thinking in a world that was neither Phoenician nor Greek but, rather, "something else." In other words, more is different, an expression used here to stress that complexity adds unpredictable value to a given phenomenon, an idea which enables us to move beyond simple "Hellenism" considered as the expected result of the conquest of Phoenicia (on applying this saying from physics to Hellenistic Phoenicia, see Bonnet 2014).

\section{Alexander's Conquest of Phoenicia: Change and Continuity}

In 333/2 BCE, four years after Darius III's accession to power, the Persian Empire was not in crisis nor, as Pierre Briant has shown (1996), a ripe fruit ready to be picked by Alexander. Certainly revolts had been followed by repression; certainly the annual tribute weighed heavily on economic growth. Yet the organization of the vast Achaemenid Empire had enabled Phoenician cities to thrive as it brought new dynamism to trade routes from the peripheries to the center, and vice versa. The potential of the provinces was developed, the road network was well maintained, and government networks of people and infrastructure were solidly established. The kingdom of Sidon, part of the satrapy of the Transeuphrates like all Phoenician cities, served as the base for the Achaemenid administrative and military network. Each Phoenician kingdom managed its own development with its own dynasty and governing bodies, while being subject to annual tribute. The material culture shows that, from the early fourth century BCE and even before, relations between the Phoenician cities and the Aegean basin were intense and regular. In fact, other than the Persian Wars, the interactions between the two shores of the eastern Mediterranean have always been strong and creative, as best exemplified in the adaptation of the Phoenician alphabet by the Greeks.

Attica was a privileged partner of the Sidonians, especially under the reign of Straton I (known as "Abdashtart" in Phoenician; 365-352 BCE), called the "philhellene," who was honored as the proxenos for the Athenians for having served as the go-between for Athe-

Page 3 of 13

PRINTED FROM OXFORD HANDBOOKS ONLINE (www.oxfordhandbooks.com). (c) Oxford University Press, 2018. All Rights Reserved. Under the terms of the licence agreement, an individual user may print out a PDF of a single chapter of a title in Oxford Handbooks Online for personal use (for details see Privacy Policy and Legal Notice). 


\section{The Hellenistic Period and Hellenization in Phoenicia}

nians and Persians (IG $\mathrm{II}^{2}, 141 ;$ ca. $\left.360 \mathrm{BCE}\right)$. Exemption from the metoikion, the choregia, and any taxes (eisphora) was granted to "as many of the Sidonians living in Sidon and enjoying civic rights as visit Athens for purposes of trade"-a clear sign of (p. 102) intense and fruitful relationships between the two groups. From the mid-fourth century BCE, the Sidonians were integrating into Athenian trade networks, settling in Piraeus, and introducing their own cults there. Alexander's conquest of Phoenicia was not a sudden turning point in Phoenician history, although the associated violence and upheavals cannot be denied. What is certain is that cultural transfers from Greece, related to arts and crafts, know-how, and language skills, did not wait for 332 BCE to disseminate along various communication routes. If by "Hellenization" we mean this sort of cultural permeability, then Phoenicia began to "Hellenize" itself from at least the fifth to fourth centuries. This is evidenced by the magnificent series of Sidonian sarcophagi (known as the Satrap, the Lycian, The Mourning Women, and Alexander, dated to the period between the late fifth and late fourth centuries BCE) inspired by models or made by artists from Asia Minor (Stucky 2015).

By slipping into the cosmopolitan structures and dynamics of the Persian Empire, Alexander certainly privileged continuity over rupture. Accordingly, the conquest strengthened exchanges with the Greek world and the processes of cultural transfer already underway. What is troubling, however, is the way in which an epic confrontation between a "civilizing" Hellenism and a "primitive and barbarian" East is staged in the narratives of conquest (Bonnet 2014). To legitimize the conquest, this narrative amplifies the break with the past. Arrian, Diodorus, Quintus Curtius, Plutarch, and Justin, despite their diversity, all furnish a Greek memory of the event, and the silence of Phoenician sources deprives us of any comparison. Furthermore, these accounts are largely posterior to the event. They fall more under the genre of heroic history, of myths associated with the sometimes revered, sometimes criticized figure of Alexander the Conqueror, founder of an empire that was as ephemeral as it was memorable (Briant 2012). One element of continuity, however, is emphasized by these sources: that of the atavistic conflict between Greeks and Persians that Herodotus had already noted (Hdt. 1.1-2). Alexander therefore comes in Achilles's footsteps to avenge a Greece humiliated by Darius I and Xerxes, to put an end to the unending wars.

On the other hand, the ancient historiography on Alexander mobilizes all the clichés about barbaric otherness and the benefits of paideia to present as a cultural mission what was actually a military conquest. While the kings of Arados, Byblos, and Sidon were sufficiently wise and farsighted to welcome Alexander as a liberator and spontaneously grant him power, the king of Tyre, supported by the entire population, gave free rein to the hubris that characterizes barbarians. The siege of Tyre lasted seven long months of unprecedented ferocity. It was a grandiose occasion for the Greek sources to highlight all that differentiated the local people, who had thrown themselves into a senseless resistance doomed to failure, from the Greeks, noble and clever, led by Alexander and assisted by the gods themselves (Herakles, Apollo), as if in Tyre the epic battle of Troy were playing out again. The narrative processes of Greek and Latin sources all sought to magnify the contributions of Alexander, the civilizing king. Even the somewhat fragile solidarity

Page 4 of 13

PRINTED FROM OXFORD HANDBOOKS ONLINE (www.oxfordhandbooks.com). (c) Oxford University Press, 2018. All Rights Reserved. Under the terms of the licence agreement, an individual user may print out a PDF of a single chapter of a title in Oxford Handbooks Online for personal use (for details see Privacy Policy and Legal Notice). 


\section{The Hellenistic Period and Hellenization in Phoenicia}

between Tyre and Carthage, which wanted to help its mother-city, is presented in a negative light, as if this East-West axis across the Mediterranean was and would always be a threat to Hellenism and its "natural" (p. 103) universalizing destiny. The conquest narratives thus construct a memory of the "Hellenization" of the Phoenician cities, sometimes spontaneous and redemptive, sometimes forced, but always legitimate. They pay little attention to the singularity of the Phoenician case, rightly emphasized by Fergus Millar (Millar 1983). In the panorama of the new Greco-Macedonian Empire, Phoenicia was indeed an exception. No Greek settlement was established there (Cohen 2006), in contrast to Syria, while the diasporic dimension of Tyre meant that the city had long been integrated into the Mediterranean-wide network of connectivity. For these reasons, the concept of "Hellenization" appears doubly inadequate to describe the dynamics specific to the Hellenistic period in Phoenicia. What happened there was something more complex, more fluid, and more creative than the simple adoption of Greek culture.

\section{The Change in Governing Frameworks}

When we speak of "Hellenization," we tend to focus on the cultural aspects, while the changes above all affected politics. Highlighting the "civilizing" benefits in the conquest narratives is a strategy that poorly masks Alexander's imperialism. The idea was to impose the power of the Greeks on the Phoenicians as a replacement for the Persians. Local people shifted from one tribute system to another, which was an essential element of continuity. Freedom, lauded by Isocrates, the herald of paideia, was reserved for the Greeks and was hardly suited to the conquered populations of barbarians! Did Alexander, heir to the structures of the Achaemenid Empire, plan to "Hellenize" the system? Would the Phoenician kingdoms turn into poleis or city-states with representative bodies such as a council and an assembly? The issue is complex (Apicella and Briquel-Chatonnet 2015) and also obscured by the incomplete source material. Local royalty governed for some time after the conquest, as evidenced by certain inscriptions and coins. While at Arados and Tyre the kings remained in place (although the latter was given a special supervisor, Philotas: Quintus Curtius 4.5.9), in Sidon, Alexander replaced the king with Abdalonymus, the gardener of royal descent who had previously been cut off from power (Bonnet 2014). Everywhere, kings pledged allegiance to Alexander and simultaneously had their privileges reduced. In the space of one or two generations (the first quarter of the third century), the kings had disappeared (Eddy 1961). Yet even before the arrival of Alexander, the Phoenician kings surrounded themselves with councils (of elders, prominent people) and/ or civic assemblies, although there is little extant information to provide more detail.

The transition from an absolute monarchy to a sort of "constitutional" one had to be done gradually under the leadership of the Greeks, as well as that of local elites who held offices and thereby served as efficient relays for Greco-Macedonian, then (p. 104) Ptolemaic and Seleucid domination. Inscriptions also show the functions of rab ("great one") and shofet ("judge, governor"), unknown in the Persian period, but well attested in the Carthaginian sphere in the group of magistrates known as suffetes, who were at the forefront of the political and social scene. Faced with the disappearance of the monarchical 


\section{The Hellenistic Period and Hellenization in Phoenicia}

model, which up to then had ordered society and its institutions, Phoenician communities found inspiration in Carthage for rethinking their internal organization and balance of power. The Greek model of the polis thus helped to transform Phoenician kingdoms: there were now assemblies, agoranomi, agonothetes, gymnasiarchs, ephebes, officials in charge of coinage, and so on. Without fully assimilating the Greek model, the Phoenician cities nevertheless experimented with new, more collegial forms of governance.

Changes in the practices of minting coinage provide evidence for this. As master of the entire region, Alexander seized the regal prerogative of minting coinage. Until the last years of the fourth century BCE, workshops in Phoenician cities produced gold Alexander coins, with the name of Alexander fully spelled out in Greek. The coins also have typical Greek symbols: Athena and Nike on the gold coins to signify the victory of Hellenism, Herakles and Zeus on the silver coins, and Herakles on bronze copies, echoing Alexander's alleged kinship with that civilizing hero. Yet these first series also mention, in Greek or Phoenician or both, the name of the local kings under whose authority the coin was issued. In its own way, therefore, coinage developed a new "language of power" (Lorber 2015). When Phoenicia came under Ptolemaic control in 301 BCE (except for Tyre in 294), Ptolemy introduced a coin with his likeness, as in Egypt. The higher powers entrusted to protect the new dynasty took on the appearance of deified Alexander, represented as the son of Zeus-Ammon. The message evokes a kind of political, cultural, and religious synthesis that the Ptolemies sought to promote all the way to Phoenicia.

The monetary policy of the Seleucids followed a different logic, progressively facilitating the autonomy of Phoenician cities. The Phoenician alphabet was given the honor of dating the coins (except Tyre, which used the Greek), while the image of the tutelary deity Tyche translated the idea of the city's power and pride into the Greek language. From 168 BCE, six Phoenician cities (Tripoli, Byblos, Berytos [i.e., Phoenician Laodicea], Sidon, Tyre and Ptolemais) launched a quasi-municipal bronze coin, with Antiochus IV on the obverse and the name of the Phoenician city on the reverse. These coins reveal a thirst for identity and a desire to exhibit the legendary glories of the past (on coins, see also chapter 25, this volume). This evolution culminated with the right to asylia in Tyre in 141 BCE and Sidon twenty years later. Around 125 BCE at Tyre, the royal Seleucid portrait was replaced by the bust of Herakles, who, although Greek in appearance, at the same time refers to the prestigious Baal of Tyre, Melqart.

We can see, then, in different places and times and in different circumstances, that Phoenician (or rather, Tyrian and Sidonian) elements and Greek elements were combined to produce messages that reflect a search for balance between dominance and autonomy, between tradition and openness, and between local and global.

\section{(p. 105) Cults and the Dynamics of Mediation}

Cultic practices, which are also largely embedded with politics, are a privileged field for mediations and multicultural arrangements (Bonnet 2014). Polytheistic systems are open but also voluntarily cumulative. This means that while each community (Tyre, Sidon, Byb- 


\section{The Hellenistic Period and Hellenization in Phoenicia}

los, Arados, etc.) had its own pantheon, rituals, and representation of the gods, the deities of others could still be accommodated when their power was likely to provide additional protection. For example, from a very early time, Phoenicians adopted Egyptian deities such as Hathor, Isis, Osiris, and Amon, which they identified with their own gods for the sake of ritual efficacy. In this area, as in those mentioned earlier, the Phoenicians did not wait for the Hellenistic period to familiarize themselves with the religious worlds of their neighbors. For instance, from the beginning of the first millennium BCE, the island of Cyprus in particular was a vast, cross-cultural experimental space in which Cypriot, Phoenician, and Greek gods were all appropriated (on Cyprus, see chapter 31, this volume).

The numerous exchange networks that brought the Mediterranean to life provided a great many opportunities to experiment with combinations or contextual equivalences, which were always contingent and empirical-nothing was dogmatic or fixed. Using names of the gods, epikleses, ritual forms, images, offices, and modes of operating and/or associating, people fashioned creative, sometimes surprising, solutions in response to the changes in the religious landscape. In fact, after Alexander's conquest, on the Phoenician coast as well as inland but to different degrees, Greeks and Phoenicians, residents and passing visitors, traders, farmers, fishermen, women, intellectuals, and artisans lived together and also shared a territory inhabited by divine entities. The concept of "Hellenism" seems to suggest a distancing from, a decline in, or an effacing of the Phoenician gods in favor of their Greek counterparts. Is this what we find in practice?

Let us take the example of Melqart, the Baal of Tyre. The accounts of the conquest of Tyre reveal a vigorous appropriation of his cult by Alexander (Bonnet 2014). It is true that the "King of the City" ( $m l k$ qrt) was the centerpiece of the legitimation of dynastic power. The Greek hero Herakles, an alleged ancestor of Alexander, seems to have completely overwhelmed the Phoenician god, as Herodotus (Hdt. 2.44) had already suggested in the fifth century. Yet had Melqart really disappeared, strangled like the Nemean lion through the power of Herakles? The answer is no: several sources show that Melqart remained truly present in the Tyrian religious landscape of the Hellenistic period. First, in Tyrian anthroponomy references to Melqart persist, particularly among the local elite (e.g., Louvre inscription AO 1441). From the Tyrian inland, moreover, there is a marble statue base bearing five lines of Phoenician dating from 100 BCE (Gubel et al. 2002, no. 123). The statue was an offering for the sanctuary of Melqart and was placed "at [the feet of Lo]rd Melqart in the sanctuary [of the Lord] forever; may he bless us!" Thus, even before the Roman conquest, Melqart was still revered in Phoenician as the Baal of the Tyrians.

(p. 106) The persistence of his cult and his importance as a tutelary god are also attested by the bronze coin-shaped tesserae mentioning the consecration of Tyre in $141 \mathrm{BCE}$ under his patronage (Abou Diwan and Sawaya 2011). Produced up to 60 BCE, these tesserae have an inscription combining Phoenician and Greek: LMLQRT BȘR/HYRW'SLS, "To/for Melqart in Tyr / hiera (holy) and asylos (inviolable)" (figures 8.1-8.2). In the linguistic métissage here, the god as guarantor of inviolability is designated in Phoenician (Melqart), while the Greek label "holy and inviolable" is transcribed phonetically in 


\section{The Hellenistic Period and Hellenization in Phoenicia}

Phoenician characters, with the coordinating conjunction kai translated into Phoenician by $w$. Even in a context where the Greek institutional influence was strong, the (p. 107) link between Tyre and Melqart was maintained and was necessarily expressed in Phoenician, which Strabo in the late first century BCE or early first century CE understood in his own way by saying that "the Tyrians worship Herakles most highly" (Geogr. 16.2.22-23). The Greek institutional framework thus ends up giving voice to Phoenician traditions and "micro-identities" (Whitmarsh 2010). A weight in the Louvre (AO 4602) dated from the third century BCE, with its legend LMLQRT/ŠT 10/BȘR ("belonging to Melqart, year 10, in Tyre") confirms the central role of this god in the economic life of the city. The presence of a vertical club on another weight, associated with the image of a palm tree (phoinix), which evokes the Greek name of Phoenicia, Phoinike, invites us to move beyond Phoenician versus Greek dichotomies. There was clearly a middle ground for devising creative and unpredictable compromises.

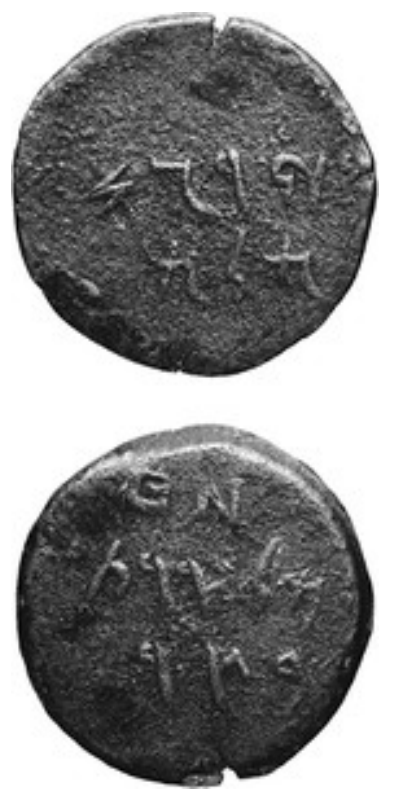

Figures 8.1 and 8.2 Coin-shaped tessera in bronze (two sides), from Tyre, from the year 55 (72/1 av. J.C.). Obverse: [L]EN / LMLQRT / BȘR. Reverse: [H]YR W ' ŠLŠ. 29.05 mm; 14.40 g. (BnF, fonds H. Seyrig 1975.25).

Source: Public.

The trend was both to "de-barbarize" local deities, to break them out of local contexts and incorporate them into international networks, and to read them through the polyvalent lens of interpretatio, as well as to exalt their power rooted in a given land. At the same time, the Greek gods-Apollo, Pan, Aphrodite, and so on-were welcomed and bridges were built through the entire arsenal of multi-perspectiveness. What one observes, ultimately, is an extremely inventive koine-linguistic figurative, cultic, and onomastic-that historians must explain as such without deconstructing it. As pointed out, "more is different" is the way to understand these phenomena and to emphasize the fact that things are more than the sum of their parts. Phoenicians employed negotiations, ruses, diversions, a 


\section{The Hellenistic Period and Hellenization in Phoenicia}

good dose of pragmatism and creativity, shared knowledge, and a strong sense of personal and collective interests. The "New Deal" of Hellenistic Phoenicia was the fruit of all these dynamics.

\section{Strategies of the Elites}

In what part of society do we find the drivers of these subtle shifts? Who is changing the scenery, cutting down or hampering the resistance, creating systems of alliance, fostering transfers? The sparse documentation shows that the elites-political, economic, and intellectual-who had much to lose and everything to gain in this "New Deal," were certainly involved, even more so because of the decline and disappearance of the royalty. The nobles who had thus lost their status, along with clever bankers, bold entrepreneurs, and generous benefactors, all showed real familiarity and even kinship with Greek culture. It contributed to their prestige and influence, as did displaying their Phoenician family roots and their attachment to ancestral gods. In this, it is legitimate to speak of hybridity to describe the culture of Hellenistic Phoenicia, since it was in no way a choice between two cultures. Rather, the cultures were combined in varying degrees depending on the contexts, by developing a capacity for cultural mimesis that promoted integration, the key to success.

These "passeurs" between local culture and Greek culture were particularly dynamic in working with networks and movements of various kinds. An inscription about (p. 108) Diotimos, a Sidonian honored by his city for winning the chariot race in the Nemean Games in Argos around $200 \mathrm{BCE}$, is one of the rare sources that opens a window onto the world of these political and cultural mediators, initiators of a new Phoenicia (Bonnet 2014). Called "judge," a Greek term that probably refers to the Phoenician shofet, or a senior magistrate, Diotimos was celebrated in an epigram in verse, in the vein of Pindar: "the first among the citizens, you brought from Hellas in the noble house of the Agenorids the glory won in an equestrian victory." It was not only Sidon praising him, but also "Thebes, the holy city of Kadmos" (Rüpke 2013: 50).

By embroidering the legendary fabric connecting Phoenicia to Greece through Kadmos, the epigram shows that at the game of emulation, that typically Greek agon, Phoenicians could equal and even surpass their masters. By highlighting Agenorid and Kadmian roots, this text also subtly reminded Greeks exercising their guardianship over the Phoenicians that the former were beholden to the later for the phoinikeia grammata, the very foundation of their culture, and that the latter could still prove their superiority, even in Greek lands. The relative loss of political autonomy was compensated for by calling on Phoenicia's ancient and brilliant cultural heritage, and by adopting typically Greek forms of sociability that were likely to promote, in return, local identities.

Ultimately, we see refined and diverse strategies charged with cultural hybridization, which allowed Phoenicians to appropriate the Greek symbolic fabric without abandoning their own culture. Greek culture, probably perceived as modern, prestigious, and cosmopolitan, was a source of distinction for elites. These elites also found, in concepts of 


\section{The Hellenistic Period and Hellenization in Phoenicia}

Phoenician ancestrality and kinship, the means for weaving several threads of belonging and affiliation together to build a polyphonic social imaginary. We find an illuminating testimony of the new cultural landscape of Hellenistic Phoenicia in the verses from the poetic collection The Garland (preserved in the Palatine Anthology), by Meleager of Gadara (100 BCE), who lived much of his life in Tyre. After having "set up his throne at the borders of culture" (AP 12.257), the poet fancies himself carving an eloquent text on his tomb (AP 7.417): "If I am a Syrian (Syros), what is the marvel (thauma)? One fatherland, stranger, is the Kosmos we inhabit. One Chaos bore all mortals" (cited by Andrade 2014: 306). Within Hellenistic Phoenicia, identities were blurred just as the boundaries that previously separated here from there, and same from different (e.g., the work of Philo of Byblos, a Phoenician writer in Roman times writing in Greek on Phoenician topics; see chapter 18, this volume).

\section{From Hellenization to the "Middle Ground"}

Let us return to the notion of "Hellenization," which should probably be rejected as far too one-sided. Moreover, for this period the concept of universalism seems premature and otherness is no longer applicable. The paradoxical fabric of this time of (p. 109) considerable interaction makes the historian's job difficult. What is clear is that to reduce the Hellenistic period to the tyranny of Hellenism is to go astray. Certainly, at this time Greek language, customs, cults, and institutions expanded everywhere, although they had also been widely known and partially adopted in previous periods. But rather than covering over and irremediably drowning Phoenician culture, these Greek influences triggered new, creative responses. Despite the real bite of Greek imperialism, what we observe is a Phoenicia in motion, neither frozen in nostalgia for the past nor stubbornly resisting threats to its heritage-a Phoenicia looking outward, long accustomed to transactions and to networks, to transfers and to compromise.

Moreover, in the eyes of the Greeks, the Phoenicians were the closest and most familiar of the "barbarians." They were the cousin on the other shore, the partner and competitor in the Mediterranean. As Isocrates's speeches show, with the Hellenistic expansion, Hellenism considered as a way of living and thinking had long irrigated the Phoenician landscape without disfiguring it and without making local culture obsolete. Therefore, Alexander's conquest in 332 BCE did not mark a sharp break but, rather, a quantitative and qualitative threshold that affected ways of doing, living, speaking, and presenting oneself. To describe the multiple drivers working in Hellenistic Phoenicia, the concept of "middle ground" borrowed from Richard White (1991) seems much more accurate and fertile than that of "Hellenization." Middle ground focuses on the spaces and actors of mediation and the creative in-betweens where cultures meet, learn to understand each other, and intertwine their destiny, without ignoring the harshness of power relations that conditioned the processes of cultural adaptation on both sides. 


\section{References}

Abou Diwan, G., and Z. Sawaya. 2011. "Les tessères monétiformes de 'Melqart à Tyr.'” Syria 88: 265-83.

Ager, S., and R. Faber, eds. 2013. Belonging and Isolation in the Hellenistic World. Toronto: University of Toronto Press.

Aliquot, J. 2009. La vie religieuse au Liban sous l'Empire romain. Beirut: Institut Français du Proche-Orient (Ifpo).

Andrade, N. 2014. "Assyrians, Syrians and the Greek Language in the Late Hellenistic and Roman Imperial Periods." Journal of Near Eastern Studies 73, no. 2: 299-317.

Apicella, C., and F. Briquel-Chatonnet. 2015. "La transition institutionnelle dans les cités phéniciennes, des Achéménides à Rome.” In La Phénicie hellénistique. Actes du colloque international de Toulouse (18-20 février 2013), edited by J. Aliquot and C. Bonnet, 9-29. Lyon: Maison de l'Orient méditerranéen.

Bonnet, C. 2014. Les enfants de Cadmos. Le paysage religieux de la Phénicie hellénistique. Paris: De Boccard.

Briant, P. 1996. Histoire de l'empire perse. De Cyrus à Alexandre. Paris: Fayard.

Briant, P. 2012. Alexandre des Lumières. Fragments d'histoire européenne. Paris: Fayard.

Cohen, G. M. 2006. The Hellenistic Settlements in Syria, the Red Basin and North Africa.

Berkeley, Los Angeles, and London: University of California Press.

(p. 110) Eddy, S. K. 1961. The King Is Dead: Studies in the Near Eastern Resistance to Hellenism, 334-31 B.C. Lincoln: University of Nebraska Press.

Grainger, J. D. 1992. Hellenistic Phoenicia. Oxford: Oxford University Press.

Gruen, E. 2005. Cultural Borrowings and Ethnic Appropriations in Antiquity. Stuttgart: Franz Steiner.

Gubel, E., A. Caubet, and E. Fontan. 2002. Art phénicien. La sculpture de tradition phénicienne. Paris: Réunion des Musées Nationaux.

Hall, J. M. 1997. Ethnic Identity in Greek Antiquity. Cambridge: Cambridge University Press.

Hall, J. M. 2002. Hellenicity: Between Ethnicity and Culture. Chicago: University of Chicago Press.

Kuhrt, A., and S. Sherwin-White, eds. 1987. Hellenism in the East. The Interaction of Greek and Non-Greek Civilizations from Syria to Central Asia after Alexander. London: Duckworth. 


\section{The Hellenistic Period and Hellenization in Phoenicia}

Lorber, C. C. 2015. "Royal Coinages in Hellenistic Phoenicia: Expressions of Continuity, Agents of Change." In La Phénicie hellénistique. Actes du colloque international de Toulouse (18-20 février 2013), edited by J. Aliquot and C. Bonnet, 55-88. Lyon: Maison de l'Orient méditerranéen.

Ma, J. 2008. "Paradigms and Paradoxes in the Hellenistic World." Studi ellenistici 20: 37185.

Malkin, I. 2011. A Small Greek World. Networks in the Ancient Mediterranean. Oxford: Oxford University Press.

Millar, F. 1983. "The Phoenician Cities: A Case Study of Hellenisation." Proceedings of the Cambridge Philological Society 209: 54-71.

Payen, P. 2005. “Introduction.” In J. G. Droysen, Histoire de l'hellénisme, edited by P. Payen, 5-82. Grenoble: J. Millon.

Rüpke, J., ed. 2013. The Individual in the Religions of the Ancient Mediterranean. Oxford and New York: Oxford University Press.

Sartre, M. 2003. D’Alexandre à Zénobie. Histoire du Levant antique. IV siècle avant J.-C. $-I I I^{e}$ siècle après J.-C. Second edition. Paris: Fayard.

Stavrianopoulou, E., ed. 2013. Shifting Social Imaginaries in the Hellenistic Period. Narrations, Practices, and Images. Leiden and Boston: Brill.

Stucky, R. 2015. "Dorf und Stadt. Griechische Präsenz an der phönizischen Küste während der Perserzeit und im fr?hen Hellenismus." In La Phénicie hellénistique. Actes du colloque international de Toulouse (18-20 février 2013), edited by J. Aliquot and C. Bonnet, 181-205. Lyon: Maison de l’Orient méditerranéen.

Versluys, M. J. 2008. "Exploring Identities in the Phoenician Hellenistic and Roman East.” Bibliotheca Orientalis 65: 342-35.

White, R. 1991. The Middle Ground: Indians, Empires and Republics in the Great Lakes Region, 1650-1815. Cambridge: Cambridge University Press.

Whitmarsh, T., ed. 2010. Local Knowledge and Microidentities in the Imperial Greek World. Greek Culture in the Roman World. Cambridge and New York: Cambridge University Press.

\section{Notes:}

$(\bullet)$ Translated from the French by Cynthia J. Johnson. 


\section{Corinne Bonnet}

Université Toulouse - Jean Jaurès 